\title{
Note by the Editors and the Administrative Board
}

As we noted in volume 23 (pp. xlvi-xlviii), the period of Franklin's mission to France brings with it roughly two and a half times as many documents as those for the other seventy years of his life. In the present volume once again we summarize a portion of his incoming correspondence in collective descriptions; they appear in the index under the following headings: consulship seekers; emigrants, would-be; favor seekers; offerers of goods and schemes.

As first noted in volume 30 (p. 1x), Franklin's French secretary Jean L'Air de Lamotte made letterbook copies of official correspondence. Many of these copies contain errors that could not have been present in Franklin's originals. Regrettably, they are in many cases the only extant versions. We publish them as they stand, pointing out and correcting errors only when they threaten to obscure Franklin's meaning.

A revised statement of textual methodology appeared in volume 28 and is repeated here. The original statement of method is found in the Introduction to the first volume, pp. xxiv-xlvii. The various developments in policy are explained in $\mathrm{xv}$, xxiv; xxi, xxxiv; xxıII, xlvi-xlviii.

As noted in volume 39 (p. liv), the digital edition of The Papers of Benjamin Franklin, conceived and sponsored by the Packard Humanities Institute, is freely accessible at www .franklinpapers.org. It contains texts of all the documents in our archive up to Franklin's death, including those that are only summarized or mentioned in the letterpress edition, as well as biographical sketches of Franklin's correspondents and an introduction by Edmund S. Morgan. Transcriptions of documents that will be included in future volumes are preliminary, and will be replaced as the letterpress edition proceeds.

All volumes of the Franklin Papers build on the work of earlier editors and assistants. Our predecessors collected and transcribed thousands of manuscripts, identified correspondents, supplied dates for undated documents, and left us the benefit of their research notes and proposed annotation. We acknowledge 
here with special appreciation the work of Claude-Anne Lopez, who died in $201 \mathrm{I}$ at the age of ninety-one. Claude joined the Franklin Papers at its inception, and spent more than thirty years transcribing, proofreading, researching, dating, and annotating documents from the eight and a half years of Franklin's residence in France. Her name appeared on the title pages of twenty-five volumes, beginning with Volume 15. She was Editor of Volume 28, and thereafter continued her association as a Consulting Editor. Claude's research notes and draft annotation remain invaluable to the current editors. We shall always miss her expertise, judgment, and wit. We also gratefully acknowledge the work of Karen Duval, an associate editor who left the project in 2006. Karen drafted preliminary annotation for some twenty documents that fall within the time period of this volume.

Assistant editors Alicia Anderson, Adrina Garbooshian, and Allegra di Bonaventura left the project as work on Volume 4I was under way. We thank them for their many contributions and wish them well. Assistant editors Ellen Pawelczak and John Huffman joined our team after the manuscript had been completed. They contributed as much as any of us to the final corrections, and we are extremely grateful. Lesley Kent provided much-needed temporary assistance with skill and good cheer. Kate Woodford, our current editorial assistant, joined us in time to assist with page proofs; we thank her for all her help. Michael Hattem, a graduate student in the Yale History Department, assisted with proofreading and research.

Finally, and with a sense of profound loss, we note that Volume $4 \mathrm{I}$ will be the last to bear the name of Edmund S. Morgan, who died in 2013 at the age of ninety-seven. Ed joined the Administrative Board in 1969 , served as its Chairman from 1992 until 2004, and remained an active member until his retirement in 2012 . No one was more committed to the success of this project than he, or more aware and appreciative of the work that went into every page. His counsel was invaluable, his wisdom irreplaceable. This edition is immeasurably richer on account of his association with it. 